\title{
To instill fear or love: Terrorist groups and the strategy of building reputation
}

Conflict Management and Peace Science 2018, Vol. 35(4) 355-377

(C) The Author(s) 2016

Reprints and permissions: sagepub.co.uk/journalsPermissions.nav DOI: I0.II77/07388942 I6634292 journals.sagepub.com/home/cmp

(\$SAGE

\author{
Seden Akcinaroglu' \\ Binghamton University, USA
}

\section{Efe Tokdemir ${ }^{*}$}

Binghamton University, USA

\begin{abstract}
Why does one terrorist group employ actions that win the hearts and minds of its constituency while another resorts to tactics that alienate their support? The paper investigates terrorist groups' strategy of building reputation in their constituency/in-group population and non-constituency/out-group population. Studying all domestic terrorist groups between 1980 and 201 I with original data, we find that ethnic/religious groups and those with territorial control invest in positive reputation in their constituency as they can minimize the risks of returns. Radical groups and those with cross-border support, however, tend to build negative constituency reputation. While the former type of group has a small constituency, the latter ones can find resources across borders, which reduces their dependency on the constituency. Lastly, we find that terror groups seeking policy concessions avoid building a negative reputation in their non-constituency as this strategy enhances their chances of negotiating with the government.
\end{abstract}

\section{Keywords}

Constituency, domestic terrorist groups, reputation building, strategy

\section{Introduction}

"They must hate Nigeria as a whole" is a common perception of Boko Haram (Agboga, 2013: 56), given how they forcibly recruit children and commit atrocities against civilians without discrimination. Known for its brutality, Boko Haram perfectly fits the negative

\footnotetext{
*Efe Tokdemir has now moved to Bilkent University, Turkey

Corresponding author:

Seden Akcinaroglu, Political Science Department, Binghamton University, Binghamton, NY I3902-6000, USA.

Email: sakcinar@binghamton.edu
} 
image associated with terrorists. Contrast this with the perception of Hamas, a group promoting itself as the savior of Palestinians. Although Hamas has acted violently against the Israeli people, it has also won the hearts and minds of Palestinians by providing medical clinics, schools, charities, drug treatment centers, mosques, and youth and sports clubs (Alexander, 2002: 11; Juergensmeyer, 2003: 78). Whereas Boko Haram appears to attack indiscriminately, Hamas's strategy instead focuses on instilling fear in Israeli civilians and inspiring love on the part of Palestinians.

What factors determine the strategies that respective terrorist groups adopt in attempting to push forward their political agendas? How do these strategies differ across each group's constituency? These are the central questions addressed in the present study, which contributes to the recent trend on group-level studies on terrorism by showing that terrorist groups differ widely in regard to the strategies they use in attempting to achieve their goals. As the example of Hamas shows, terrorist groups may engage in good deeds (Blanford, 2011; Norton, 2007; Roy, 2013), a concept that makes sense only when we study the group's actions, and the target of its actions as part of a comprehensive strategy. Any given terrorist group may engage in a range of actions, and certainly not all terrorist groups take actions that positively impact the communities they claim to serve.

It is the purpose of this study to ascertain the circumstances in which terrorist groups take specific actions whereby they establish a reputation and the reasons for these actions. This is the first study to code actions intended to build reputation. We analyze group actions both toward each terrorist group's constituency, the group of people they claim to represent, or in other words, in-group members, and toward their non-constituency, the group of people not represented by the terrorist group, in other words, out-group members.

We assume that the actions of terrorist groups in both audiences are driven by a simple cost-benefit calculation. While all terrorist groups may want to benefit from the rewards of undertaking actions with the intent to build a positive reputation, for example, popular support, committed and voluntary recruits and funds, these actions are rather costly. We find that groups only adopt positive actions if they can minimize the inherent risks. Our results also indicate that ethnic/religious groups, mainly groups whose community is bound by a common identity, and those controlling a territory, are better equipped to minimize risks and reap the benefits of adopting actions intended to build a positive reputation. Radical groups, and those with cross-border support, are less reliant on their constituencies and are better off forgoing costly actions and instead securing resources by coercion. Lastly, we find that group strategies toward their non-constituency heavily hinge on group goals - those seeking policy concessions are expected to restrain violence in order to secure wider public sympathy and compliance.

We begin by discussing the literature on terrorism, and then we consider the apparent cost-benefit calculations that terrorist groups make in deciding to pursue a given strategy. We then hypothesize about the conditions under which terrorist groups build a positive/negative reputation within a constituency and non-constituency. Next, in the 'Research design' section, we offer a detailed explanation of the coding rules we developed to define the level of reputation for each group, after which we test our claims in the 'Results' section. In the closing sections, we present a brief discussion of our findings and a conclusion.

\section{Group-level studies on terrorism}

Recently, the quantitative literature on terrorism has shifted its focus to group-level analysis, with scholars offering explanations of some interesting phenomena in relation to terrorists, such 
as what causes groups to cease functioning, the factors that contribute to the relative longevity or brevity of their existence, and the extent to which their attacks are lethal and/or intense (Asal and Rethemeyer, 2008; Cronin, 2009; Daxecker and Hess, 2013; Horowitz and Potter, 2014; Jones and Libicki, 2008; Mierau, 2013; Nemeth, 2014; Young and Dugan, 2014).

Group-level quantitative studies, however, are rare. In particular, we know very little about why terrorist groups pursue any given strategy in attempting to achieve their ends. The few studies that examine the lethality of terrorist groups (Asal and Rethemeyer, 2008; Mierau, 2013) conclude that religious groups cause more casualties. These studies indicate that the type of the terrorist group is an important factor in the strategy selected, for example, the extent of the violence perpetrated. In defining the strategies used by terrorist groups, however, we should address not only the actions selected by each group, but also the targets of those actions. Based on a single case study or a limited number of empirical examples, some scholars have shown that violence leads to concessions (Kydd and Walter, 2006; Pape, 2005) and is, therefore, a rational strategy. In Lake's (2002) model, violence helps extremist terrorist groups by provoking the state; the state's brutality then leads to backlash. However, the assumption that terrorist groups widely and indiscriminately attack at all times, with minimal interest in the target, is not empirically justified. In his study of 28 terrorist groups, Abrahms (2006) shows that terrorism has only limited effectiveness as a tool of coercion. Similarly, Cronin (2009) argues that groups engaged in continual violence are more likely to fail in achieving their goals. We agree with the latter scholars that violence may be destructive for the group, but we ask what the exact circumstances are. By studying the decision calculus of terrorist groups based on a cost-benefit analysis, we seek to explore when terrorist groups find it optimal to avoid negative actions such as extreme violence.

To study group actions, which we call reputation-building behavior, we first define the target audience of each terrorist group, namely its constituency and non-constituency. We also define a terrorist group's strategy as a complete plan of action-a plan that incorporates actions for both targets. We study a broad spectrum of negative actions that go beyond civilian violence, but we also analyze positive actions.

Scholars have acknowledged that some terrorist groups do good deeds. Associating terrorists with good behavior, although counterintuitive, again makes sense when we examine terrorists' actions in conjunction with the targets selected. A few studies have looked at the public goods provided by Hamas and Hezbollah in the areas in which the constituency of each resides (Alexander, 2002; Blanford, 2011; Juergensmeyer, 2003; Norton, 2007; Roy, 2013), and some have argued that by skillfully manipulating the media and engaging in grassroots political agitation, terrorist groups can acquire some measure of legitimacy (Neumann and Smith, 2005). However, these findings are not generalizable. In the present study, we explore a broader set of strategies employed by all domestic terrorist groups by analyzing a series of positive actions that are intended to build a positive reputation across their constituencies. Altogether, we seek to shed light on which groups tend to undertake strategies of this nature.

\section{Strategies of terrorist groups: reputation building}

We define reputation as a collective and common assessment of a terrorist group based on its behavior that results in either a favorable or an unfavorable attitude toward a group on the part of a given audience (Carreras et al., 2013). Terrorism is defined as the premeditated use (or threat) of violence by sub-national groups in the pursuit of political, economic, 
social, and/or religious goals with the aim of intimidating and influencing an audience beyond its immediate victims (GTD). Whether they aim to overthrow a regime or to gain political concessions from a regime, terrorist groups rely heavily on media attention to spread the news of their violent actions. In order to achieve their political objectives, however, terrorist groups must secure and sustain sources of recruits and funding. Terrorist operations are expensive, and terrorists need both human and material resources in order to plan and carry out attacks. Terrorists choose strategies - the type of action and its targetin order to maximize media attention and thereby attract the recruits and funding that are required to sustain their operations.

Terrorist groups face two types of audiences. The first is the people the group claims to represent - herein referred to as the constituency (in-group population) - which can be an ethnic and/or a religious group (e.g. the Kurdistan Workers' Party (PKK), which represents Kurds in Turkey) or an ideological group (e.g. Action Directe, which represents leftists in France). The second audience- herein referred to as the non-constituency (out-group population) - comprises all the people who are not members of their constituency in the terrorist group's country, that is, the people whom terrorist groups do not claim to serve in any way. These constitute the wider public that is often targeted by terrorist groups. For example, Turks in Turkey are the non-constituency of the PKK. While both audiences matter to terrorist groups, this distinction addresses the in-group/out-group bias heavily emphasized in psychological theories of terrorism (Friedland, 1992; Stern 1999; Taylor and Ryan 1988; Weinberg and Eubank, 1994). These studies share the perspective that terrorism begins with differences between the two groups that are exacerbated by a threat to one's values, security, or welfare (Borgeson and Valeri, 2009). According to Taylor and Louis (2005), the out-group population is specifically crucial in shaping the identity of terrorists. Other scholars demonstrate how in-group/out-group bias determines group strategies and molds individual attitudes toward violence (Friedland, 1992; Struch and Schwartz, 1989).

When making this distinction, we do not claim that all individuals associate with their group's identity or ideology, nor do we claim that terrorist groups always target people from an out-group population. We also accept that group boundaries may be insignificant for some groups. However, distinguishing between separate audiences allows us to capture the differences between terrorist groups, some of which may have salient and some only fluid boundaries for in-group vs out-group membership. Specifically, terrorist groups that utilize and emphasize in-group/out-group boundaries should target non-constituencies disproportionately, as the costs and benefits of doing so widely differ. This implies different reputation-building strategies in the two audiences. Although terrorists seek to shape the behavior of their constituencies by punishing people for non-compliant behavior, coercing compliance or preventing defection, attacks on others is not conditional on behavioral change. For example, the PKK has carried out attacks on both Kurds and Turks. Its attacks on Kurds were designed to coerce their support, whereas its attacks on Turks aimed to gain publicity, spread fear, and coerce concessions from the state. Calculations of benefits from the group's good behavior differ, too. For example, the PKK seeks to recruit only Kurds. Thus, looking at the relationship between a terrorist group and the entire population as a single audience would make it impossible to discover the strategic calculations groups make in regard to the people they claim to represent vs those they don't. The idea that terrorist groups may be behaving differently toward these two groups of people is also demonstrated by survey findings that establish individual sympathy for a terrorist group being contingent on one's identity (Karakoc and Sarigil, 2016; Whyte, 1990). The gap in the way that Kurds 
and Turks perceive the PKK (Karakoc and Sarigil, 2016), or in the way that Catholics and Protestants perceive the IRA (Whyte, 1990), provides evidence that reputation building is likely to be different in the two audiences for many groups. Thus, we believe that this distinction is justified.

In order to achieve their objectives, terrorists seek to establish and implement optimal strategies in regard to each population. Each strategy employed by the group, however, has costs and benefits and comes with risks of one kind or another. Costs refer to the use and depreciation of material and non-material resources. For example, if a terrorist group were to serve its constituency by building a hospital, financial resources, effort/time, and manpower would be needed. Similarly, an attack on a military facility requires funds, sophisticated weaponry, and manpower. Furthermore, any given action may involve loss of resources. For example, men allocated to a mission may lose their lives, weapons may be lost, and captured terrorists may give up important intelligence on the group, all of which increase the initial costs of the strategy. Terrorist groups seek returns from each investment in the form of funds, recruitment, support, and publicity. However, a group may fail to realize such returns owing to the existence of risk, defined as the chance that the actual return will be lower than the anticipated return with the possibility of loss. The extent to which any terrorist group takes risks in pursuing any given action varies based on the competence of the group, the effectiveness of counterterrorism strategies (the ability of the state to use security forces and supply economic goods to curb terrorist activity), free riding (the inability to generate individual participation arising from the principle of non-excludability of public goods), and local resistance (the failure to increase local support because of ideological or ethical/moral barriers in the population). For example, building a hospital may not give rise to the expected constituency support in the presence of free-riding, local resistance, or obstruction on the part of the state. Similarly, attacking non-civilians is risky if the state's military forces are strong.

Terrorist groups can choose among a range of strategies. For example, a group can employ tactics that win the hearts and minds of people (leading to a positive reputation) within its constituency, thereby guaranteeing a flow of recruits and funds to carry out violent acts and ensure that the group's voice is heard. Alternatively, a terrorist group may employ coercive methods (actions leading to a negative reputation), such as abducting civilians or extorting funds to maintain the supply of resources necessary for its survival. The former strategy is costly in the short run; that is, it requires the use of the group's scarce means. However, in the long run, a terrorist group may benefit by securing free human and material resources via this strategy. In sum, these strategies offer high expected returns by leading to a positive reputation, but the associated risks - counterterrorism, free riding, local resistance - mean that the group may find itself unable to recover initial costs. Thus, losses are expected to be high given the extent of the risk.

Coercive tactics, on the other hand, are less costly in the short run as they do not require abundant resources. Yet these tactics must be maintained and closely monitored in the long run, as the flow of material and non-material resources obtained from the constituency is not provided voluntarily. The supply of recruits and funds would also come to a swift end if people were not living in a constant state of fear. Low-cost strategies, overall, diminish the group's popularity and offer limited returns. The risk is also correspondingly low, as coercion eliminates free riding and local resistance is lower in the presence of fear. This means that even when these strategies are not capitalized in the long run owing to effective counterterrorism strategies, terrorist groups lose little in regard to sunk costs. 
In order to achieve their objectives, terrorist groups also choose actions in regard to their non-constituency. Their non-constituency includes people who generally support the government and its policies against the group as well as fence-sitters who are not particularly in favor of or against the government (Fortna, 2015). The non-constituency is generally subjected to most of any given terrorist group's threats and violence. Terror tactics, such as detonating a bomb in a crowded area, targeting civilians randomly and causing massive casualties, produce the publicity the group seeks. Actions such as these are relatively inexpensive, as they require few funds and little manpower, and the risks are low as detection is difficult. These actions, however, quickly disaffect the out-group population, some of whom might otherwise sympathize with the group's grievances. Alternatively, terrorist groups may opt for strategies that require selective targeting, such as attacking military or police forces. Selective targeting is costly, as it requires both manpower and sophisticated weaponry. Furthermore, the risk and the cost of detection are high, that is, mission failure and military confrontation, both of which deplete the group's resources. However, although costly, this strategy offers great benefits in regard to the group's non-constituency by preventing mass alienation - which is especially important in consideration of fence-sitters whose sympathy and support are undecided.

\section{Building a positive reputation within the constituency}

Terrorist groups that aim to build a positive reputation in their constituencies must have an incentive to invest significantly in strategies designed to meet this goal. For example, a group may disseminate its political message by establishing and operating a political wing. The political arm of the Moro National Liberation Front in the Philippines, for example, consisted of a central committee, various bureaus, and a series of provincial and local committees (McKenna, 1998), through which the group communicated its political goals to its Muslim constituents, thereby garnering support for the group. This political investment supports indoctrination efforts, which attract recruits devoted to the group's goals. Adopting strategies that lead to a positive reputation is especially significant for terrorist groups, which are often perceived as cruel, inhumane, and as engaging in senseless violence rather than in legitimate military action. Terrorist groups that establish a political wing, however, are obliged to invest in trained and experienced political staff and pour time and resources into creating local committees.

Terrorist groups may also use their own press, radio, and films to engage in clever propaganda campaigns to disseminate their message to their constituencies (Pekgozlu et al., 2007). By disseminating information on the daily activities, successes, and grievances of the group, the media highlights the sacrifices of terrorist groups on behalf of their constituencies, thereby lending some credibility to groups of this nature. Terrorist groups' propaganda, which often includes publications, also attracts recruits by enhancing the social status of those participating in violence (Flanigan, 2008). The Revolutionary Armed Forces of Colombia (FARC), for example, broadcasts its "Voice of Resistance" radio program with six mobile transmitters. Similarly, Hezbollah uses its global satellite, Al Manar, as an effective propaganda tool. There is no doubt that this station has already generated ample returns given that it has become one of the most popular channels in the region and has inspired resistance among Hezbollah supporters. However, its annual budget of US\$15 million renders this a very expensive strategy (Jorisch, 2004). 
A terrorist group can also try to improve its image within its constituency by providing much-needed services such as health care, education, and food. The institutions that provide these goods, such as hospitals, schools, charities, and orphanages, socialize people according to the ideology of the group and mold youth to become voluntary recruits (Levitt, 2004). The provision of goods to supporters and their families also improves a terrorist group's chances of creating and sustaining a militia peopled by recruits committed to the group's objectives and willing to engage in suicide attacks (Berman and Laitin, 2008). By demonstrating competence in governance, addressing the needs of its constituency, and distributing goods, a terrorist group can shift the loyalty of the people away from the government. Such activities provide a terrorist group's supporters with day jobs, cloak the group in a veil of legitimacy, and help build grassroots support (Levitt, 2007). However, all such activities also require funds. According to Levitt (2007), Hezbollah's support of Al-Janoub Hospital in southern Lebanon totals US\$1.2 million annually. Given the high cost of such activities, the questions are these: which terrorist groups find it optimal to build a positive reputation in their constituencies despite these high costs, and why?

As noted, the strategies outlined have the potential to yield significant benefits. Yet, not all terrorist groups find it optimal to implement them given the relative risk involved. Even if a terrorist group spends millions of dollars in its constituency and devotes manpower with the skills and training to implement a given strategy, there is no guarantee that such efforts will bear fruit. On the contrary, the presence of risk is a deterrent when the initial costs of a strategy are high. Should the venture fail, the terrorist group would find itself in a position of having wasted precious resources that could have been used for other purposes. Thus, terrorist groups only pursue such strategies when the potential for significant rewards is high and when the risk is minimized.

We argue that it is easier to for a terrorist group to garner support and empathy when its constituency is an ethnic/religious group with well-defined distinct histories, cultures, ethnic traits and/or religious traditions. By focusing on a specific ethnic/religious community, or in other words, an identity-based community, as opposed to leftist or utopian groups with broad goals and a less-defined constituency, terrorists benefit from the existence of a clearly defined audience with bounded membership (Byman, 1998). Not only do ethnic/religious identities, "those based on common descent, experience, language and belief tend to be stronger and more enduring than most civil and associational identities" (Walter, 2004: 372), but the barriers to membership over the years also help forge dense social networks and ties that bind members together. This, in turn, facilitates mobilization. When a terrorist group invests in political indoctrination and activism within its own ranks, for example, by convincing trusted leaders and elders of an ethnic/religious community to join the group's cause, it is likely that others will follow suit (Gorenburg, 2003). Identity-based groups also have an advantage over other types of groups, as the political agenda of the former often finds "some resonance with a preexisting, well-defined group of people" (Byman, 1998: 6). Thus, by engaging in violence in retaliation for the discrimination they, rightly or wrongly, perceive themselves as subject to, ethnic/religious groups can easily legitimize their actions and benefit from far greater constituency support than ideologically motivated groups do (Walter, 1996). The result is a decrease in local resistance.

Ethnic/religious constituencies offer another advantage to terrorist groups: violence on the part of the terrorists and counter-violence on the part of the state drive a wedge between rival populations and thus create a severe security dilemma (Posen, 1993). Ethnic/religious identities are likely to be more distinguishable than political identities are, creating an easy 
target for rival communities. This increases the dependence of ethnic/religious constituencies on terrorist groups that are claiming to fight for their rights. Within aggrieved ethnic/religious communities then, group affiliation becomes a source of mutual insurance when terrorist groups provide protection and/or other types of goods and services such as health care, income, and food based on ethnic/religious identity. In turn, such goods and services bind terrorist groups to requisite ethnic/religious communities (beneficiaries) in a web of trust and affection that lowers constituency resistance against the group.

Taking positive actions within ethnic/religious communities not only produces high returns for the terrorist group, but also guarantees the availability of exactly the kind of recruits the terrorists seek. The availability of information on the histories of people in ethnic/religious communities enables terrorist groups to find recruits based on community reputation. That is, through pre-existing networks, terrorist groups can identify and manage committed militants, thereby minimizing moral hazard (Weinstein, 2007). By using tribal and religious leaders and local committees, ethnic/religious terrorists can also implement mechanisms to monitor communities and apply sanctions to defectors, thus minimizing free riding.

Lastly, in a society bound by kinship, counterterrorism strategies are also less likely to be effective, as the state, if it has a rival identity, as is often the case, is unlikely to infiltrate or succeed in efforts to gather local intelligence on a terrorist group under such conditions (Caselli and Wilbur, 2013; Dingley, 2012). The British, for example, had difficulty monitoring and controlling the community of Catholics, who were not inclined to cooperate with the Crown, which they perceived through a hostile lens (Dingley, 2012). By restricting group membership to those identified by common ties of blood and ethnicity, ethnic/religious terrorists can also limit infiltration by agents of the state by identifying and excluding potential informants from their ranks (Enders and Sandler, 2006). More importantly, harsh state responses can render ethnic/religious identity more salient and engender broader support for the terrorist group (Byman, 1998). All of this means less risk for the terrorist group. Knowing a strategy that is costly now can be capitalized later in the form of committed and loyal recruits, ethnic/religious terrorist groups find it profitable to take positive actions among their constituencies and reap the benefits of the positive reputation that automatically follows such actions. In short, the risks of adopting positive strategies are likely to be less significant for ethnic/religious groups than for other groups.

Hypothesis 1: Ethnic/religious terrorist groups are more likely to act with the apparent intention of building a positive reputation in their respective constituencies compared with ideological groups.

Given the high initial and operating costs of taking a positive action, terrorist groups need to find ways to secure returns from their strategies. Indeed, by establishing political branches in government-supported areas, broadcasting news in areas where the service is frequently hacked or interrupted, or providing health services in a region where the group's supporters do not reside may not generate buy-in and may even bolster local resistance. The result is precious resources wasted. As the sole military and security provider in an area, a terrorist group can patrol its borders and establish several checkpoints in order to minimize risk and maximize returns on its strategy. Terrorist groups gaining a monopoly on violence in a geographic area can thus increase benefits by careful targeting and effective monitoring in order to minimize the adverse effects of the state's counterterrorism efforts. For example, in 2006 
Hezbollah's territorial control was so strong that when Israeli jets bombarded the Al-Manar headquarters the same year, Hezbollah's broadcasts were interrupted for less than two minutes (Zarb, 2011).

Indeed, territorial control means that a terrorist group has the military means to monopolize mass communication, gain political office, and provide welfare services, each of which renders the constituency more dependent on the terrorist group that is, in this sense, its patron. Military control of an area also brings constant contact with the constituents in the territory. Repeated interactions between the terrorist group and the people deepen the ties between the two and reduce local resistance, especially when the latter are beneficiaries of social, political, and public goods provided by the terrorist group in a bid to engender trust, solidarity and loyalty. Military dominance also provides a terrorist group with the means to establish local mechanisms to detect and reward good behavior and punish defections among the population (Kalyvas, 2006). This, in return, reduces free riding, one of the risks of default on the group's strategy. Territorial control, thus, minimizes risks associated with efforts to build a positive reputation.

Hypothesis 2: Terrorist groups with territorial control are more likely to act with the apparent intention of building a positive reputation in their respective constituencies than groups without control.

\section{Building a negative reputation within a constituency}

Not all terrorist groups find it profitable to employ positive actions, perhaps because some of these groups may find it difficult to minimize the risks involved in high-cost strategies. It appears that terrorist groups prefer to pursue low-cost strategies and take negative actions instead. As an alternative to providing costly political and social goods to constituents, terrorist groups can secure much-needed recruits and funds by coercion in order to increase support. Terrorists do not incur high operational costs either when forcing civilians to provide food, shelter, or money or when abducting children and adults from villages where unarmed residents cannot protect themselves. In Uganda, for example, the Lord's Resistance Army has used bands of as few as five militants to steal medicine from health clinics and to abduct children (Human Rights Watch/Africa, 1997). However, although the costs of this strategy are low, so are the benefits. Coercion increases the number of uncommitted and undisciplined members of a terrorist group and alienates the constituency, which jeopardizes the terrorist group's reputation (Mason and Krane, 1989; Weinstein, 2007). Coercive recruitment also necessitates constant monitoring, as the recruits are likely to be non-compliant and eager to escape (Eck, 2014). Given the minimal benefits of building a negative reputation, which terrorist groups prefer to invest in coercive policies and why?

Some terrorist groups, principally those with a heterogeneous constituency, find it suboptimal to pour significant resources into strategies designed to build a positive reputation. Radical terrorist groups, that is, groups aiming to transform the existing regime, are often unappealing to the masses. Boko Haram, with its radical Jihadist agenda, for example, does not appeal to the majority of Muslims despite the clear division that exists between Muslims and Christians in Nigeria. Thus, attempts to gain legitimacy by providing goods or through media broadcasting are likely to meet with limited success. Such strategies can only buy the loyalty of a limited number of people in the constituency, a population unlikely to be large 
enough to bring any strategic advantage to the terrorist group. The risks are also likely to be high, as moderates display resistance toward the terrorist group and counterterrorism efforts on the part of the state are likely to be fruitful when a substantial number of people in the constituency are not committed to the terrorist group's agenda. Owing to the risks, therefore, radical groups may elect to employ coercive policies. Indeed, like Boko Haram, AlShabaab, another Jihadist group operating in Somalia, has increasingly used forced recruitment (Lynch, 2013) in order to bolster their shrinking ranks and has even targeted children as young as 10 for action on the frontline.

Hypothesis 3: Radical terrorist groups are more likely to act with the apparent intention of building a negative reputation in their respective constituencies than non-radical groups.

Terrorist groups with cross-border support have the means to obtain recruits and funds from both their domestic constituency and foreign populations. The existence of multiple sources of recruits reduces a terrorist group's dependence on its own constituency. Terrorist groups, therefore, find it less useful to employ costly strategies in their constituencies, given the risks, when they have the luxury of relying on foreign populations for support. The PKK, a group that defends the rights of the Kurdish minority in Turkey, for example, was also able to rely on Kurdish support in the rival states of Syria and Iran during the 1980s and 1990s. Having the luxury of recruiting Syrian Kurds during this time, the PKK did not hesitate to act violently (e.g. by raiding villages and massacring their residents) in Kurdish towns in Turkey, which dramatically reduced its base of support among Turkish Kurds (Khalil, 2007). As the PKK's dependence on its constituency increased with the improvement of Turkey's relations with Syria and Iran, however, the terrorist group began to avoid indiscriminate violence and shifted its targets to military units.

In short, terrorist groups that have the luxury of not relying on their constituencies may prefer to pursue low-cost strategies. Although employing coercion within its constituency may yield limited benefits of limited worth for a terrorist group - a supply of uncommitted recruits - the group can hedge against the risks of this strategy when it has access to foreign populations to offset the adverse effects of this strategy. Should its fear-induced recruitment strategy backfire by, for example, alienating large numbers of people and leading to mass defections among its core supporters, a terrorist group can salvage some of its expected returns by shifting its attention to cross-border locations where it can find recruits. A terrorist group with logistical support, a safe haven, and/or training facilities across borders can, therefore, lower the cost-benefit ratio of adopting coercive strategies in its constituency.

Hypothesis 4: Terrorist groups with cross-border support are more likely to act with the apparent intention of building a negative reputation in their respective constituencies than groups with no support.

\section{Building a reputation within non-constituency}

Terrorist groups also decide on what they consider to be the optimal strategy to influence their non-constituency. As we have argued in this study, selective targeting is a high-cost strategy requiring manpower, funds, and sophisticated weaponry, all of which may be wasted 
by a failed mission as this is a high-risk strategy whereby a terrorist group is exposed to better armed and funded security forces. In return, however, the terrorist group may gain the sympathy of some members of its out-group populace. So which terrorist groups find it optimal to engage in selective targeting?

We argue that a terrorist group can bear a high risk only when the benefits of a strategy justify the associated risks, for example, when the benefits help the group to achieve its objective. This is a possibility only when terrorist groups aim for policy concessions, an outcome that government leaders may consent to if groups have support from the mainstream population, that is, the people in the non-constituency of the terrorist group. Negotiating with terrorists, especially when large numbers of civilians have been victims of the group's activities, would otherwise be very costly for any political leader. The political outcomes of violence have been consistently negative (Abrahms, 2006). For example, when the IRA committed atrocities against the British public, the political views of the out-group population on not giving in to terrorists hardened (Neumann and Smith, 2005). Similarly, Klerk, the President of South Africa, asked the opinion of his own constituency, the white population of South Africa, before making concrete concessions to the African National Congress (ANC) in 1992, a group fighting to dismantle the apartheid regime in South Africa. The referendum outcome of sharing power with blacks was supported by two-thirds of the whites, an outcome that would have been impossible had the ANC been the target of resentment by the white population. Terrorist groups that pursue a strategy of selective targeting minimize the resentment of civilians in their non-constituency, thereby removing an obstacle to their efforts to negotiate with the government.

Any terrorist group that aims to overthrow the regime, or create a separatist state, however, is not likely to garner either support or sympathy from the individuals in the out-group no matter what strategy is pursued. The aspirations of separatist terrorists are usually perceived as a great threat to the sovereignty and territorial unity of a state (Merrari, 1993). Political leaders face severe domestic risks when making territorial concessions, especially to terrorist groups. Further, terrorist groups with extreme agendas such as seeking to overthrow a regime are unlikely to appeal to the majority of their non-constituency. Thus, given the risks and limited benefits of high-cost strategies, terrorist groups aiming for more than policy concessions tend to avoid such strategies.

Hypothesis 5: Terrorist groups aiming to secure policy concessions are more likely to avoid actions that might lead to a negative reputation within their non-constituency than non-policy-oriented groups.

\section{Research design}

To test our hypotheses on strategies of positive and negative actions that lead to reputation building, we structure our data for terrorist groups from 1980 to 2011 . We do not analyze activities before 1980 since there is a dearth of reliable data available on the activities of terrorist groups before that year. However, our data range covers both the Cold War and postCold War eras, which provides a sufficient range of terrorist groups operating under various geo-political constraints for our purpose. Since our focus is on violent non-state actors that have used terror tactics, our sample was selected from Enders et al.'s (2011) set of domestic terrorist groups in the GTD (START, 2013), operating under a specific group name that 
had each been involved in at least five attacks over a period of one year or more. One of the problems with using GTD database is that $40 \%$ of the attacks listed in the database are unclaimed. Given that unclaimed attacks are not random (Arva and Beieler, 2014), we may be creating a systematic bias into our study when we use civilian casualties as an indicator of non-constituency reputation. We accept this bias and caution scholars on the limitations of our data and findings.

Our criteria of exclusion of young groups is solely driven by data concerns; information is expected to be extremely scarce on groups with limited existence and including those groups would severely increase the data bias due to underreporting. Some of the omitted groups are also expected to be one-hit wonders, or lone wolf actors, individual terrorists unaffiliated with a formal organization. Overall our data include 443 terrorist groups operating over 31 years, which yielded a total of 2641 observations.

\section{Dependent variables}

We used three dependent variables to test our hypotheses: actions intended to build a positive reputation within a constituency; actions intended to build a negative reputation within a constituency; and actions intended to build a negative reputation within the nonconstituency (see Online Appendix A for coding constituency vs the non-constituency, data sources and limitations). Given that our argument focuses on policy choices rather than on policy effectiveness, we measured the type and number of positive and negative actions each terrorist group pursued in order to build a reputation in both its constituency and its nonconstituency.

To measure actions undertaken with the apparent intention of building a positive constituency reputation, we collected original data (Tokdemir and Akcinaroglu, 2016) on whether the terrorist groups provided public goods and had media power and/or a political existence. If a terrorist group provided goods such as free education, security, health services, transportation, and/or communication facilities, we coded the provision of public goods as 1, otherwise as 0 . Second, if a terrorist group owned a television and/or a radio channel for broadcasting, we coded the group's media power as 1. Lastly, if the terrorist group was originally established as a political party, was associated with a political wing/branch, or affiliated with any political party during its existence as a terrorist group, we coded its political power as 1 . Finally, summing these three variables, we established a $0-3$ scale to represent each terrorist group's apparent intention to build a positive reputation within constituency.

In order to measure each group's apparent intention to build a negative reputation within constituency, we coded each group's forced-recruitment, child-recruitment, and forcedfunding activities. First, we coded forced recruitment when the terrorist group used involuntary conscription of civilians. Second, we coded child recruitment: terrorist groups that resorted to recruiting children as either soldiers or trainee soldiers were coded as 1. Lastly, we coded groups that used forced funding, such as extortion activities or revolutionary taxes, or any activity that forced people to contribute to the cause against their will. Finally, by combining all three variables, we created an ordinal variable ranging from 0 to 3 as an indicator of each group's apparent intention to build a negative constituency reputation.

We did not code positive reputation within the non-constituency, only the extent of negative reputation. ${ }^{2}$ As terrorism challenges the status quo, that is, the system that currently benefits the non-constituency, a terrorist group's goals and activities are not expected to appeal to the non-constituency. By default, most terrorist groups achieve some level of negative 
non-constituency reputation, as they often commit acts of violence that cause fear in their out-group population (Hoffman, 2010; Wright, 2011). However, the extent to which terrorist groups are cautious in using indiscriminate violence tactics, in our opinion, varies. To code actions intended to build non-constituency reputation, we used two indicators: civilian casualties $^{3}$ and the targeting of children. First, we coded mass civilian casualties to indicate the extent to which terrorist groups victimize their non-constituency. As terrorist groups kill civilians in a bid to alter the behavior of governments, most civilian victims of terrorist activity tend to be members of the out-group population. We used the GTD to measure civilian casualties inflicted by each terrorist group. We took the country-year mean as the threshold for measuring "excessive brutality", and we coded this variable as 1 when the number of civilian casualties met this threshold, otherwise we coded it as 0 . In addition to civilian casualties, the killing of children generates massive criticism from the wider audience. Terrorism is deplorable in the eyes of the public because terrorist tactics victimize innocent people. It is bad enough when a bomb explosion targets an adult but when the terrorist group directly attacks children, the action is morally incomprehensible. Thus, we coded the presence/absence of a direct attack on children as a binary variable. Combining civilian casualties and the targeting of children, we created an ordinal variable, from 0 to 2 , to indicate each terrorist group's apparent intention to build a negative reputation within its non-constituency. Higher scores indicate actions that lead to a worse reputation within its out-group population. A group that is extremely careful not to alienate its non-constituency will score 0 .

\section{Independent variables}

The independent variables for positive constituency reputation are identity (ethnic/religious) groups and territorial control. We used Asal et al.'s (2009) BAAD Database Lethality Data to code the former, and we filled in the missing values. We coded the identity variable from the BAAD database while updating it. This variable is coded as 1 if the terrorist group was either ethnic and/or religious as opposed to left-wing or right-wing. We coded territorial control as a time-variant variable if a terrorist group exerted control over a well-defined territorial area and induced civilian collaboration from the residents (Mampilly, 2011). Our independent variables for negative constituency reputation are cross-border and radical. We coded domestic terrorist groups crossing the border for logistical reasons, for example, to find a safe haven, to engage in training, etc., as 1. Next, updating Jones and Libicki's (2008) End of Terror dataset, we also created a binary variable for radical goals which is similar to the "broad/maximalist goal" variable from Jones and Libicki (2008). If the terrorist group targeted regime change, social revolution (altering individuals' social/cultural norms), or empire (overthrowing multiple regimes and establishing a single sovereign authority), we recoded this variable as 1 , and as 0 otherwise. According to this definition, groups seeking policy or territorial concessions, including secession, such as the PKK or LTTE, are considered to be non-radical. Lastly, we used one independent variable, policy change, to explain non-constituency reputation. Using the terrorist group's goal from the End of Terror dataset, we created a binary variable coded as 1 if the terrorist group sought political concessions and as 0 otherwise (see Online Appendix B for the descriptive statistics). 


\section{Control variables}

We added several control variables to our models. At the group level, we control for each terrorist group's age, as older groups are more likely to invest in reputation building and also for state sponsorship, as having access to external resources might decrease dependency on internal resources and hence the constituency. We also control for groups' peak size, as weaker groups may be more prone to hitting softer targets and using coercion to obtain much-needed constituency support than stronger groups are (Eck, 2014; Polo and Gledistch, 2014). Lastly, we control for rebel terrorists, as they may care more about constituency relations (Polo and Gledistch, 2014).

Contextual factors are effective in shaping terrorist groups' strategies; scholars have found that authoritarian regimes increase terrorism (Krueger and Maleckova, 2003) and poverty motivates extremism (Burgoon, 2006). Both can facilitate recruitment, making negative actions less relevant. We, therefore, added some national-level control variables such as the polity score from Polity IV (Marshall and Jaggers, 2002) and the GDP per capita of the country of operation (UN Statistics Division). Additionally, we controlled for the post-Cold War era, as the end of the Cold War brought international coordination on counterterrorism policies, increasing the risks of group strategies. We controlled for military personnel in each nation, as in states with strong military forces, the risks associated with high-cost strategies are higher than in states without relatively weak forces. Lastly, we controlled for competition, as it can reduce the number of resources available to each group (Young and Dugan, 2014), forcing each terrorist group to take positive actions in order to distinguish itself from the others, or to take negative actions to survive.

\section{Model specification}

Our three dependent variables are ordinal with high scores indicating a high level of positive/negative reputation for each group. Ordered logit is a viable option. However, this model imposes a proportional odds/parallel regressions assumption that is often violated. Indeed, the Brant test confirms this (see Online Appendix D). The use of ordered logit in this case would have erroneously yielded a single coefficient with different interceptions for each outcome. To solve this problem, we could treat the dependent variables as if they were not ordinal and look at the effects of each category of interest separately using a multinomial logit model. We decided to employ a generalized ordered logit model instead, which "can estimate models that are less restrictive than ... parallel lines models estimated by ordered logit ... but more parsimonious and interpretable than those estimated by a non-ordinal method, such as multinomial logistic regression" (Williams, 2006). The use of this model relaxes the parallel regressions assumption but allows the effect of each explanatory variable to change at the point where the categories of the dependent variable are dichotomized (Williams, 2005). We used the autofit command in Stata, which allows only those variables that violate the assumption of parallel lines in the model to be regressed as unconstrained while keeping the constraint of proportionality for others.

\section{Results}

In Table 1, we present the generalized ordered logistic regression results. As the model relaxes the assumption of parallel regression lines, the effect may vary at each level of the 


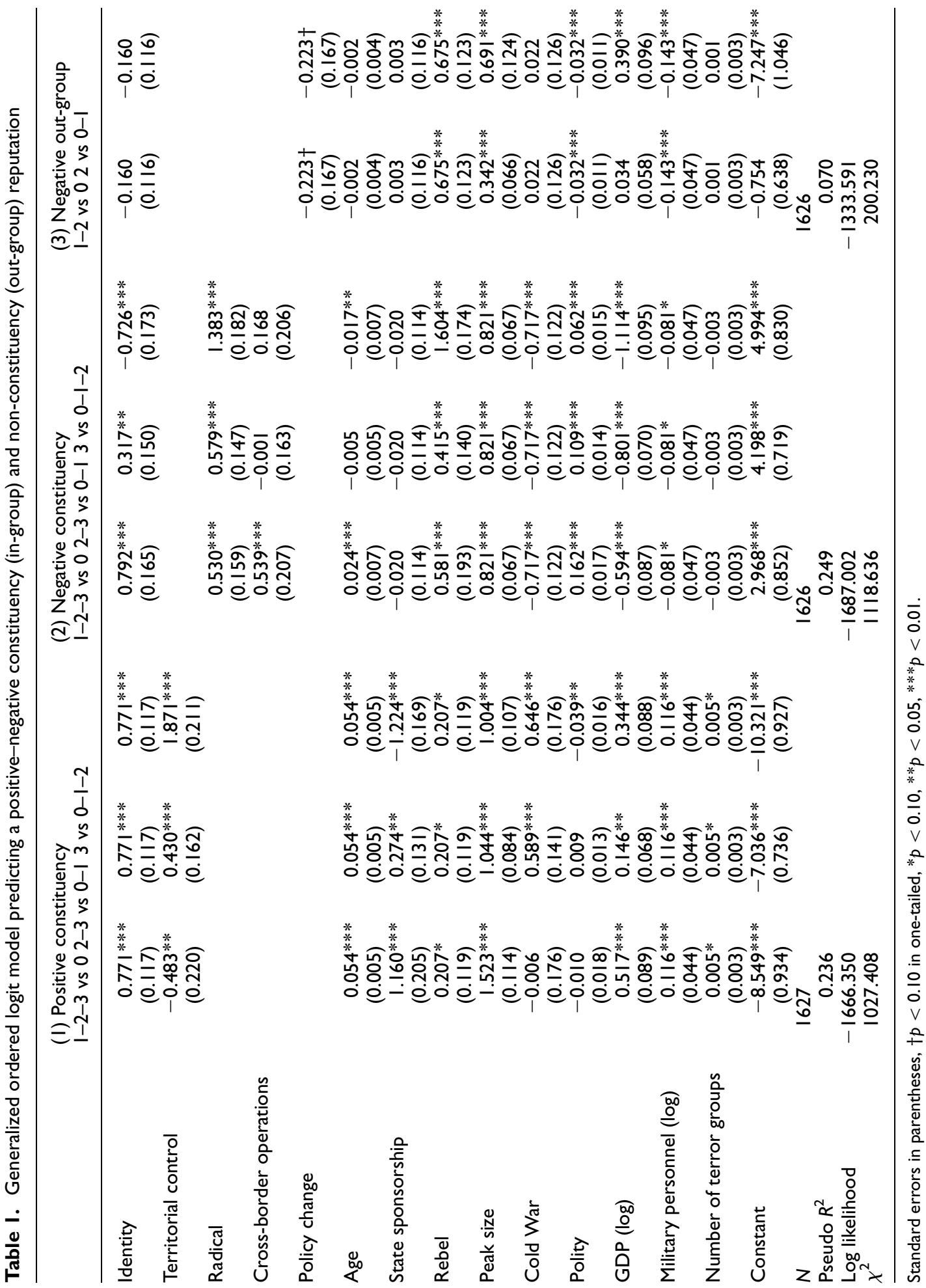


outcome variable. In other words, the coefficients of each independent variable may differ as we move along the ordinal thresholds. In generalized ordered models where the dependent variable has more than two categories, the model becomes equivalent to a combined series of binary logistic regressions (Williams, 2005). Our dependent variable, constituency reputation, has four categories from 0 (no reputation) to 3 (highest reputation). The first column in model 1 in Table 1 shows the effects of engaging in reputation-building actions (1-2-3 vs 0 ), the second column compares the effects of medium-level reputation actions (23 vs $0-1$ ), and the third column compares the impact of high reputation-building actions ( 3 vs $0-1-2) .{ }^{4}$ As expected, the larger coefficients across each column in the model reflect the increasing effect of the independent variables on the terrorist groups' decision to invest in actions that yield additional units of constituency reputation.

The first set of results shows the effects of identity (ethnic/religious) groups and territorial control on actions designed to build a positive constituency reputation. The results are statistically significant and in the expected direction across each category. Accordingly, both identity groups and those with territorial control tend to build a positive constituency reputation as compared with other terrorist groups. Furthermore, the coefficients on territorial control increase across categories as terrorist groups move toward building a stronger constituency reputation. This is not surprising as territorial control often facilitates actions that have high operating costs, and thus are only undertaken at high levels of reputation building (Mampilly, 2011).

In Figure 1, setting all other variables at their means (non-binary variables) and modes (binary variables), we calculated the predicted probability of the terrorist groups building each level of positive constituency reputation (from 0 to 3 ). It is evident that ethnic/religious terrorist groups are more likely to act with the intention of building medium and high levels of positive constituency reputation compared with ideological groups. The same holds for groups with territorial control. Although the results presented in Table 1 support both Hypotheses 1 and 2, Figure 1(a and b) reveals an unexpected finding: both ethnic/religious terrorists and those with territorial control are less likely to act with the intention of building a positive constituency reputation compared with those in the reference category at a lower level. Indeed, the impact of being an ethnic/religious terrorist group or one with territorial control on building a positive reputation becomes substantive, but mostly after the threshold for a low level of reputation building has been crossed.

In the second set of results presented in Table 1, we show that radical terrorists and those with cross-border support are overall both more likely to adopt strategies with the apparent intention of building a negative constituency reputation. The variables of interest are statistically significant in the expected direction. In Figure 1(c and d), we present the predicted probability of building each level of negative constituency reputation (from non-existent, 0 , to high, 3). Again, Figure 1(c and d) indicates that neither groups with cross-border support nor those that are radical tend to act differently from others at low threshold of negative constituency reputation.

Lastly, the third set of results in Table 1 confirms that terrorist groups aiming for policy concessions are less likely to employ actions that lead to a negative out-group reputation. Our variable of interest, policy change, is negative and statistically significant. The findings show that the government would incur high domestic costs for giving in to terrorists when the terrorist group is perceived to be vicious and brutal. Thus, policy-oriented terrorist groups shy away from such strategies. Figure 2 gives additional support to our expectations - principally that the predicted probability of building a negative out-group 

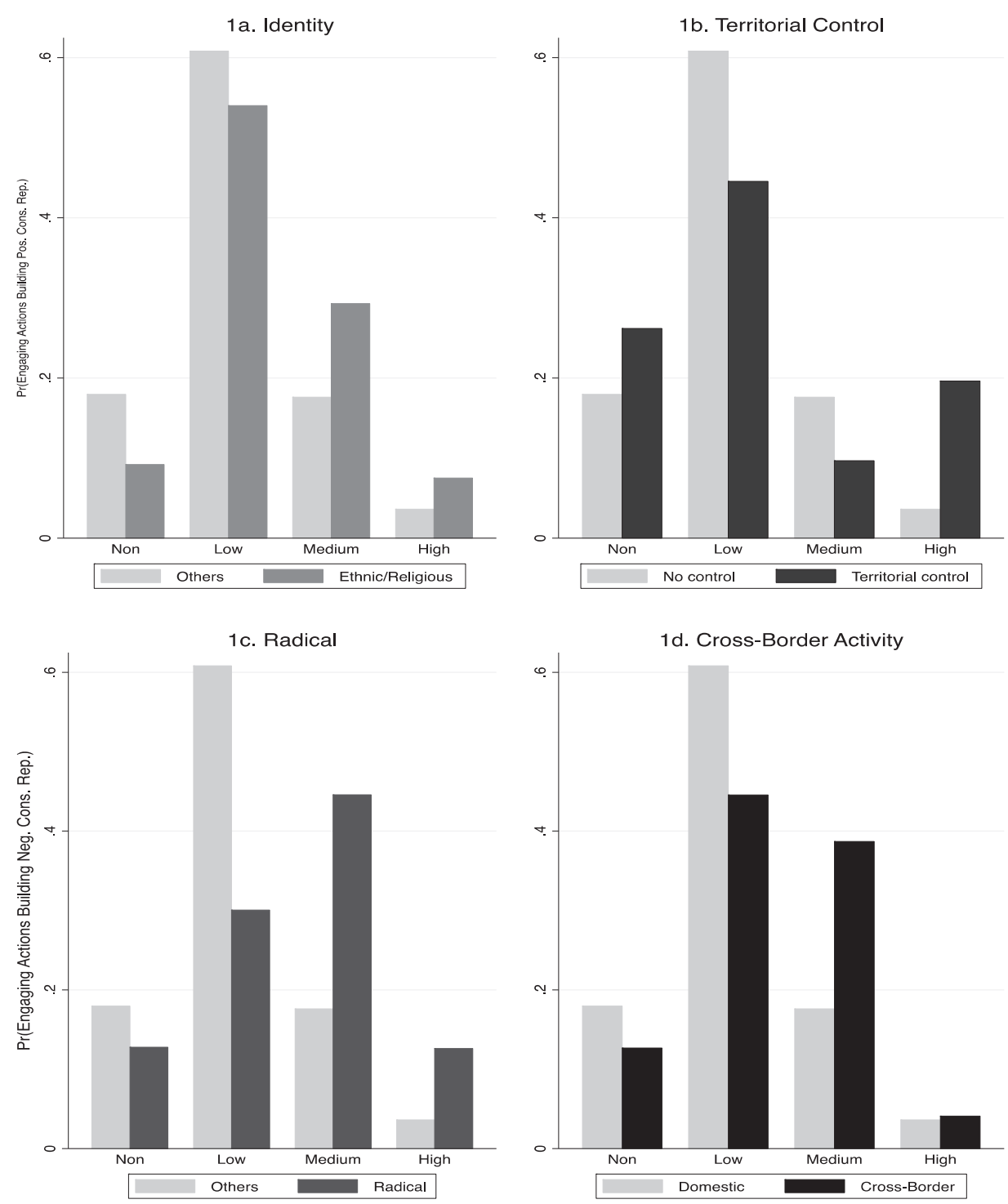

Figure I. Predicted probabilities of building positive-negative constituency (in-group) reputation.

reputation is lower for terrorist groups pursuing policy change than for those not pursuing it.

With the exception of key independent variables, we found that both older groups and those with state sponsorship tend to build a positive constituency reputation. One drawback is that sponsored groups do not invest in extremely high reputation; this may be because such groups do not need to develop highly dependent relations with their constituency, as their fate does not hinge on the acquisition of internal resources. While group size helps build reputation, it does not help differentiate groups in terms of the type of reputation 


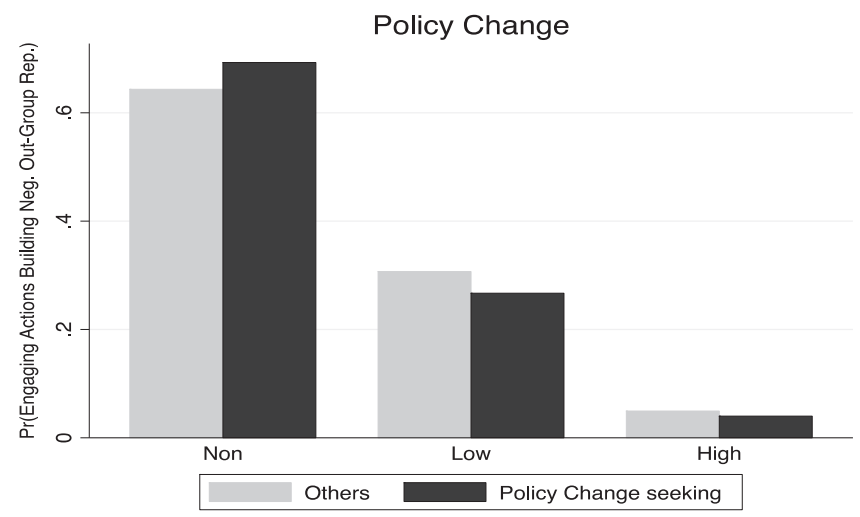

Figure 2. Predicted probability of building a negative non-constituency (out-group) reputation.

building that is likely to occur. Surprisingly, in countries with high polity scores, terrorist groups tend to have a worse constituency reputation than those operating in countries with low polity scores. In democratic countries, public goods are likely to be more extensive than in non-democratic countries and citizens, even those included in the terrorist group's constituency may be beneficiaries of the welfare programs available from government sources. Under such conditions, terrorist groups would find that the actions through which a positive constituency reputation can be built in other circumstances are not likely to generate the expected returns. Lastly, competition leads groups to invest in positive actions as a brand name.

\section{Robustness checks}

Figures 1 and 2 revealed that terrorist groups did not behave differently from each other in terms of building a positive and negative constituency reputation at low levels. Put simply, the effects of the variables of interest on actions taken to build either a positive or a negative constituency reputation were only activated once a terrorist group had undertaken a minimum level of positive/negative action. To address this problem, we recoded all our dependent variables as a binary variable heeding the critical threshold for each type of strategy (Figures 1 and 2). Thus, for negative constituency reputation and for positive constituency reputation, we combined the categories of no-action $(=0)$ with actions intended to build low reputation $(=1)$ and coded it as 0 . We also combined the categories of actions intended to build medium $(=2)$ and high reputation $(=3)$ to create a new category coded as 1 . In regard to out-group reputation, we created a new category by merging low $(=1)$ and high $(=2)$ as 1 , otherwise as 0 . We ran a series of logit models to determine the robustness of our previous findings. Overall, we found statistical support to confirm most of our hypotheses (see Online Appendix F).

The frequencies in our data reveal that some strategies, such as forced funding and the establishment of a political branch, are relatively straightforward and low cost such that the majority of terrorist groups pursue them. Rather than combining categories in order to specify the critical threshold after which terrorist groups behave differently, another option is to relax the assumption of ordinal categories and use a multinomial probit model instead. 
We graphed the coefficients with $95 \%$ confidence intervals, and the results are again largely consistent with those of previous models, which show that our findings are robust across different estimators (see Online Appendix G).

While applying group level analysis with terrorist group-year as our unit of analysis, we also control for state-level factors in our empirical models. One potential problem with the current modeling strategy is it may generate an ecological fallacy as country-level variation may be the driving force behind terrorist groups' actions intended to build reputation. Therefore, we also ran a series of multilevel mixed-effects ordered probit model as a robustness check (see Online Appendix H). Our findings are robust to multilevel modeling as well.

We also checked the validity of our indicators for measuring the extent to which a reputation is positive or negative. Are we, in fact, measuring three distinct dimensions of reputation, and do these indicators help measure those dimensions? Using factor analysis, we checked the appropriateness of grouping these indicators under three separate dimensions of reputation building and found our indicators to be valid for measuring reputation (see Online Appendix C).

\section{Discussion}

By focusing exclusively on when groups apparently intend to build either a positive or negative reputation, we omit why and when groups could use mixed strategies, that is employ both positive and negative actions concurrently. According to Eck (2014), the concurrent use of positive and negative actions is a function of conflict dynamics; mainly battle losses or external shocks force groups to initiate coercive tactics for recruitment. Our data show that a mixed strategy is common among groups that have failed to build the highest levels of positive/negative reputation (see Online Appendix I). However, our work does not contradict mixed strategizing. While we hypothesize that ethnic/religious terrorists may be inclined to engage in positive actions whereas radical groups and those with cross-border support may be inclined to take actions leading to a negative reputation, we are aware that these are not mutually exclusive categories. Our findings indicate that ethnic/religious groups that are radical or have cross-border support engage in both, that is, adopt mixed strategies. Thus, we would expect an ethnic/religious group with cross-border support such as the PKK to build some level of positive or negative reputation owing to $\mathrm{H} 1$ and $\mathrm{H} 4$. Indeed, although the PKK has invested in political indoctrination by broadcasting on its own Kurdish TV station, it has also used coercive tactics from time to time that have alienated its constituency.

\section{Concluding remarks}

In this paper, we argued that the actions of terrorist groups in regard to reputation building differ widely from each other, and that these actions could only be identified as a strategy if they were specified in relation to a target population. Terrorist groups, we argued, try to minimize the costs and risks associated with each strategy before deciding on one. Although engaging in positive actions that build a positive reputation, such as maintaining a media outlet, providing public goods, or engaging in political activities is costly, these strategies tend to offer high returns in the form of voluntary recruits likely to be dedicated to the cause. We claimed that ethnic/religious terrorist groups could minimize the risks and guarantee returns from positive actions when they targeted beneficiaries based on common 
identity ties. Additionally, we claimed that terrorist groups with territorial control would be better equipped to capitalize on the returns of their strategy as the military dominance of the group minimized disruption to the provision of services. Indeed, our findings confirmed our expectations that compared with other terrorist groups, ethnic/religious terrorist groups and those with territorial control were more likely to attempt to build a positive constituency reputation.

Second, we argued that although the costs and risks of negative actions that led to a negative constituency reputation through forced funding and forced recruitment were low, so were the returns. Terrorist groups with cross-border support, we argued, were not reliant on their constituency to the extent that others were which minimized the need to elicit their support via positive actions. Additionally, radical terrorist groups, we hypothesized, were less likely to attempt to gain a positive reputation when most of the members of their constituency failed to sympathize with their radical agenda. Failing to minimize the risks associated with building a positive, and rather costly, constituency reputation, these groups tended to adopt coercive methods to find the necessary recruits and funding. Our findings supported both claims.

Lastly, we showed that terrorist groups also cared about their reputation in their non-constituency. We argued that terrorist groups were less inclined to use indiscriminate violence if their main objective tended to be policy concessions. Our results confirmed that politically driven terrorist groups were more likely to avoid civilian casualties, especially children, in the hope of negotiating with the government.

In the present study, we treated terrorist groups as distinct entities with different agendas and survival strategies and thereby furthered our understanding of such groups. Future research could develop the concept of the reputation of terrorist groups not only by looking at domestic constituencies, as we did, but also by looking at international ones. For example, terrorist groups may find supporters among international constituencies who sympathize with their cause and donate to their activities.

The dependent variables that we coded, constituency and non-constituency reputation, can also be used to explain interesting phenomena, such as terrorist groups' survival and conflict outcomes. The bargaining power of terrorist groups, for example, is reliant not solely on their size but also on their popularity and image. Terrorist groups investing in winning the hearts and minds of their constituencies can pose distinct challenges to governments. Future studies should also invest more in group-level theorizing and testing and should refrain from treating terrorist groups as identical. Our dataset, which provides additional group-level data on terrorist groups' strategies, should provide a foundation to scholars who aim to contribute to that trend.

\section{Author note}

All data, replication materials, and instructions regarding analytical materials upon which published claims rely are available in the Online Appendix through the SAGE CMPS website.

\section{Funding}

This research received no specific grant from any funding agency in the public, commercial, or not-forprofit sectors. 


\section{Notes}

1. Author names are written in alphabetical order.

2. We believe this is plausible given that terrorist groups rarely employ strategies to appeal to the outgroup, for example, provide public goods in their non-constituency, advertise on their radio station or TV channel to appeal to their views, or establish a political party with an agenda that appeals to an out-group population.

3. There is a debate about whether civilian casualties increase or decrease constituency reputation (see Online Appendix $\mathrm{C}$ for a description of the validity of our indicators).

4. Reporting the results of generalized ordered estimations requires a large space, as the model compares different categories of the dependent variable. Owing to space limitations, we report alternative model specifications (e.g. models including only the key independent variables) in Online Appendix E.

\section{References}

Abrahms M (2006) Why terrorism does not work. International Security 31(2): 42-78.

Agboga P (2013) Weekends are for Loving. Bloomington, IN: Westbow Press.

Alexander Y (2002) Palestinian Religious Terrorism: Hamas and Islamic Jihad. London: Transnational.

Arva B and Beieler J (2014) Dealing with missing data in group-level studies of terrorism. Presented at APSA Annual Meeting, 28-31 August 2014, Washington, DC.

Asal V and Rethemeyer RK (2008) The nature of the beast: Terrorist organizational characteristics and organizational lethality. Journal of Politics 70(2): 437-449.

Asal V, Rethemeyer RK and Anderson I (2009) Big Allied and Dangerous (BAAD) Database. Lethality data, 1998-2005. Available from: https://dataverse.harvard.edu/dataset.xhtml? persistentId $=$ hdl $\% 3$ A1902.1/16062

Berman E and Laitin DD (2008) Religion, terrorism and public goods: Testing the club model. Journal of Public Economics 92(10-11): 1942-1967.

Blanford N (2011) Warriors of God: Inside Hezbollah's Thirty-Year Struggle against Israel. New York: Random House.

Borgeson K and Valeri R (2009) Terrorism in America. Burlington, MA: Jones and Bartlett.

Byman D (1998) The logic of ethnic terrorism. Studies in Conflict and Terrorism Spring: 149-169.

Burgoon B (2006) On welfare and terror. Journal of Conflict Resolution 50(2): 176-203.

Carreras E, Alloza Á and Carreras A (2013) Corporate Reputation. London: LID.

Caselli F and Coleman WJ (2013) On the theory of ethnic conflict. Journal of European Economic Association 32(11): 161-192.

Cronin KA (2009) How Terrorism Ends. Understanding the Decline and Demise of Terrorist Campaigns. Princeton, NJ: Princeton University Press.

Daxecker UE and Hess ML (2013) Repression hurts coercive government responses and the demise of terrorist campaigns. British Journal of Political Science 43(3): 559-577.

Dingley J (2012) The IRA: The Irish Republican. Santa Barbara,CA: Praeger.

Eck K (2014) Coercion in rebel recruitment. Security Studies 23: 364-398.

Enders W and Sandler T (2006) The Political Economy of Terrorism. Cambridge: Cambridge University Press.

Enders W, Sandler T and Gaibulloev K (2011) Domestic versus transnational terrorism: Data, decomposition, and dynamics. Journal of Peace Research 48(3): 319-337.

Flanigan ST (2008) Nonprofit service provision by insurgent organizations: The cases of Hizballah and the Tamil Tigers. Studies in Conflict and Terrorism 31: 499-519.

Fortna P (2015) Do terroists win? Rebels' use of terrorism and civil war outcomes. International Organization 69(3): 519-556. 
Friedland N (1992) Becoming a terrorist: Social and individual antecedents. In: Howard L (ed.), Terrorism: Roots, Impact, Responses. New York: Praeger.

Gorenburg DP (2003) Minority Ethnic Mobilization in the Russian Federation. Cambridge: Cambridge University Press.

Hoffman B (2010) Voice and silence in terrorist campaigns: Why groups take credit for acts of terror. Journal of Peace Research 47(5): 615-626.

Horowitz MC and Potter PBK (2014) Allying to kill: Terrorist intergroup cooperation and the consequences for lethality. Journal of Conflict Resolution 58(2): 199-215.

Human Rights Watch/Africa (1997) The scars of death: Children abducted by the Lord's Resistance Army in Uganda. Available from: http://www.hrw.org/reports/1997/09/18/scars-death (accessed March 2014).

Jones SG and Libicki MC (2008) How Terrorist Groups End: Lessons for Countering Al-Qaida. Monograph MG-741-1. Santa Monica, CA: RAND.

Jorisch A (2004) Beacon of hatred: Inside Hizballah's Al Manar television. Washington Institute, Monographs and Special Studies. Available from http://www.washingtoninstitute.org/policyanalysis/view/beacon-of-hatred-inside-hizballahs-al-manar-television (accessed January 2014).

Juergensmeyer M (2003) Terror in the Mind of God: The Global Rise of Religious Violence. Berkeley, CA: University of California Press.

Kalyvas S (2006) The Logic of Violence in Civil Wars. Cambridge: Cambridge University Press.

Karakoc E and Sarigil Z (2016) Who supports secession? Determinants of secession among Turkey's Kurds. Nations and Nationalism (in press).

Khalil L (2007). Turkey and the PKK. In: Forest JF (ed.), Countering Terrorism and Insurgency in the $21^{\text {st }}$ Century: International Perspectives. New York: Praeger Security International, pp. 388-408.

Krueger AB and Maleckova J (2002) The economics and the education of suicide bombers. The New Republic, pp. 27-33.

Kydd AH and Walter B (2006) The strategies of terrorism. International Security 31(1): 49-80.

Lake D (2002) Rational extremism, understanding terrorism in the twenty-first century. Dialogue IO 1(1): 15-29.

Levitt M (2004) Hamas from cradle to grave. Middle East Quarterly 11: 1-12.

Levitt M (2007) Hezbollah finances: Funding the Party of God. In: Giraldo JK and Trinkunas HA (eds), Terrorism Financing and State Responses: A Comparative Perspective. Stanford, CA: Stanford University Press, pp. 134-152.

Lynch C (2013) Thousands of additional troops urged for force in Somalia National Security, 16 October. Available from: http://www.washingtonpost.com/world/national-security/thousands-ofadditional-troops-urged-for-force-in-somalia/2013/10/16/8e1767f0-366e-11e3-8a0e-

4e2cf80831fc_story.html

Mampilly Z (2011) Rebel Governance and Civilian Life during War. Ithaca, NY: Cornell University Press.

Marshall MG and Jaggers K (2002) Polity IV Project: Political Regime Characteristics and Transitions, 1800-2002. Available from: http://www.systemicpeace.org/inscrdata.html

Mason TD and Krane DA (1989) The political economy of death squads: Toward a theory of the impact of state-sanctioned terror. International Studies Quarterly 33: 175-198.

McKenna TM (1998) Muslim Rulers and Rebels: Everyday Politics and Armed Separatism in the Southern Philippines. Berkeley, CA: University of California Press.

Merrari A (1993) Terrorism as a strategy of insurgency. Terrorism and Political Violence 5(4): 213-251.

Mierau JM (2013) The activity and lethality of militant groups: Ideology, capacity and environment. Working Paper. Available from: http://ideas.repec.org/p/dgr/rugsom/13007-eef.html (accessed January 2014).

Nemeth S (2014) The effect of competition on terrorist group operations. Journal of Conflict Resolution 58(2): 336-362. 
Neumann R and Smith M (2005) Strategic terrorism: The framework and its fallacies. Journal of Strategic Studies 28(4): 571-595.

Norton AR (2007) Hezbollah. A Short History. Princeton, NJ: Princeton University Press.

Pape RA (2005) Dying to Win: The Strategic Logic of Suicide Terrorism. New York: Random House.

Pekgozlu I, Habib O and Erkan E (2007) Communication methods in terrorist organizations: A case study of Al-Qaida connected terrorism in Turkey. In: Ozeren S, Dincer Gunes I and Al-Badayneh DM (eds), Understanding Terrorism: Analysis of Sociological and Psychological Aspects. Amsterdam: IOS Press, pp. 281-293.

Polo S and Gledistch S (2014) Twisting arms and sending messages: Terrorist activity in civil war. Presented at Network of European Peace Scientists Annual Conference, 23-25 June.

Posen B (1993) The security dilemma and ethnic conflict. Survival 35(1): 27-47.

Roy S (2013) Hamas and the transformation(s) of political Islam in Palestine. Current History 101(13): $13-20$.

START (2013) Global Terrorism Database [Data file]. National Consortium for the Study of Terrorism and Responses to Terrorism. Available from: http://www.start.umd.edu/gtd

Stern J (1999) The Ultimate Terrorists. Cambridge, MA: Harvard University Press.

Struch N and Schwartz SH (1989) Intergroup aggression: Its predictors and distinctions from ingroup bias. Journal of Personality and Social Psychology 56: 364-373.

Taylor DM and Louis W (2005) Terrorism and the quest for identity. In: Moghaddam FM and Marsella AJ (eds), Understanding Terrorism. Washington, DC: American Psychological Association, pp. 169-186.

Taylor M and Ryan H (1988) Fanaticism, political suicide and terrorism. Terrorism 11: 91-111.

Tokdemir E and Akcinaroglu S (2016) Reputation of terror groups dataset: Measuring popularity of terror groups. Journal of Peace Research; doi: 10.1177/0022343315626506 1-10.

Walter B (2004) Does conflict beget conflict? Explaining recurring civil war. Journal of Conflict Resolution 41(3): 371-388.

Walter L (1996) Postmodern terrorism. Foreign Affairs Sep/Oct: 24-37.

Weinberg L and Eubank WL (1994) Cultural differences in the behavior of terrorists. Terrorism and Political Violence 6: 1-28.

Weinstein J (2007) Inside Rebellion: The Politics of Insurgent Violence. New York: Cambridge University Press.

Williams R (2005) Gologit2: A program for generalized logistic regression/ partial proportional odds models for ordinal dependent variables. Stata, Gologit2 Manual.

Williams R (2006) Generalized ordered logit/partial proportional odds models for ordinal dependent variables. The Stata Journal 6(1): 58-82.

Wilkinson P (1989) A view from the north. In: Thomas C and Paikiasothy S (eds), Conflict and Consensus in South/North Security. Cambridge: Cambridge University Press, p. 179.

Whyte J (1990) Interpreting Northern Ireland. Oxford: Oxford University Press.

Wright AL (2011) Why do terrorists claim credit? Unpublished manuscript. Available from http:// www.princeton.edu/politics/about/file-repository/public/Wright_CreditTaking_11.3.2011.pdf

Young JK and Dugan L (2014) Survival of the fittest: Why terrorist groups endure. Perspectives on Terrorism 8(2): 1-23.

Zarb Z (2011) Channel of Resistance in Lebann: Liberation, Propoganda, Hezbollah and the Media. London: I.B. Tauris. 